Monika Schwarz-Friesel

\title{
"Antisemitism 2.0"-The Spreading of Jew-hatred on the World Wide Web
}

This article focuses on the rising problem of internet antisemitism and online hatred against Israel. Antisemitism 2.0 is found on all web platforms, not just in right-wing social media but also on the online commentary sections of quality media and on everyday web pages. The internet shows Jew-hatred in all its various contemporary forms, from overt death threats to more subtle manifestations articulated as indirect speech acts. The spreading of antisemitic texts and pictures on all accessible as well as seemingly non-radical platforms, their rapid and multiple distribution on the World Wide Web, a discourse domain less controlled than other media, is by now a common phenomenon within the space of public online communication. As a result, the increasing importance of Web 2.0 communication makes antisemitism generally more acceptable in mainstream discourse and leads to a normalization of anti-Jewish utterances.

Empirical results from a longitudinal corpus study are presented and discussed in this article. They show how centuries old anti-Jewish stereotypes are persistently reproduced across different social strata. The data confirm that hate speech against Jews on online platforms follows the pattern of classical antisemitism. Although many of them are camouflaged as "criticism of Israel," they are rooted in the ancient and medieval stereotypes and mental models of Jew hostility. Thus, the "Israelization of antisemitism," the most dominant manifestation of Judeophobia today, proves to be merely a new garb for the age-old Jew hatred. However, the easy accessibility and the omnipresence of antisemitism on the web 2.0 enhances and intensifies the spreading of Jew-hatred, and its propagation on social media leads to a normalization of antisemitic communication, thinking, and feeling.

1 M. Schwarz-Friesel and J. Reinharz, "The Israelization of Antisemitism," The Jerusalem Post, February 16, 2017, https://www.jpost.com/Opinion/The-Israelization-of-antisemitism-481835.

Ә OpenAccess. (C) 2019 Monika Schwarz-Friesel, published by De Gruyter. (cc) BY-NC-ND This work is licensed under the Creative Commons Attribution-NonCommercial-NoDerivatives 4.0 License. 


\section{Antisemitism Today: The New Hatred is the Old Hatred}

After more than sixty years of education relating to the Holocaust, innumerable media discussions and conferences, political declarations, and thousands of scientific books, films, and articles that aim to clarify the roots, the major conceptualizations, the irrational character, and the perils of antisemitism, not only is the phenomenon in the twenty-first century alive and virulent, it is also very much on the rise. The Web 2.0 plays a significant role in spreading and accelerating antisemitic texts, pictures, and films: Jew hatred has exploded in the internet, as data from a long term study reveals. ${ }^{2}$ In the last ten years, the volume of antisemitic comments in online commentary sections has tripled, in some realms even quintupled. In a ten-year comparative study (2007 to 2017), corpus studies examining the comments sections of the quality online media in Germany reveal a significant increase from 7.5 percent to 30 percent in verbal antisemitism. At the same time, we observe a tendency towards a semantic and argumentative radicalization: The prevalence of comparisons with the Nazi regime, fantasies of violence, as well as an extreme, demonizing and dehumanizing pejorative language (plague, cancer, filth) have doubled since 2009. This demonstrates the lowering of the taboo threshold regarding the articulation of even such explicit and extreme expressions of antisemitism.

At the same time, the tendency to relativize, to defend, and to deny contemporary antisemitism can be witnessed in our society, this trend is coupled with heightened indifference and an obvious lack of empathy. Our empirical data show that more than 33 percent (mean value) of antisemitic comments on the web are connected explicitly or implicitly to the Jewish state. Israel, as "the collective Jew," has by now become the major projection ground for antisemitic thoughts and feelings. Thus, contemporary Jew-hatred focuses on this most important symbol of Judaism, Jewish life, and existence. This "Israelization of antisemitism" is found in the right, the left, and in the middle of society. ${ }^{3}$ Its main feature is the projection of age-old Judeophobic stereotypes onto the Jewish state. In innumerable texts, Israel is described as a "greedy, revengeful, land robbing” and an "illegal state that uses brutal force, murders children, kills inno-

2 Cf. M. Schwarz-Friesel, “Antisemitism 2.0. Hostility towards Jews as a Cultural Constant and Collective Emotional Value in the Digital age,” longitudinal corpus study, Technische Universität Berlin, Berlin, 2018. https://www.linguistik.tu-berlin.de/menue/antisemitismus_2_0/.

3 Cf. M. Schwarz-Friesel and J. Reinharz, Inside the Antisemitic Mind: The Language of Jew-Hatred in Contemporary Germany (Boston: University Press of New England, 2017). 
cent people," "practices a genocide on the Palestinians," and "grabs for the power in the world." Muslim antisemitism, too, is determined primarily by classical stereotypes and reveals a strong religious dimension. Eliminatory death threats are dominant. As data show: Classical hostility towards Jews remains the primary conceptual basis for present-day hatred of Jews; 54.02 percent (mean value) of all expressions of antisemitism display classical stereotypes.

We distinguish between the stereotypes of classical antisemitism (ClA), which characterized discourse until 1945, the concepts of the post-Holocaust phase (PHA) after 1945, which gave rise to the stereotypes of Holocaust exploitation, resentful unforgiveness, and taboos on criticism. These post-Holocaust stereotypes ultimately rest upon the classical stereotypes of Jewish vengeance, greed, and exercise of power but have been adopted to a modern context projected onto the experience of Auschwitz and should be seen in the context of the rejection of guilt, the refusal to remember, and the antisemitism of the desire to be free of feelings of guilt (Entlastungsantisemitismus). In the research, these are sometimes referred to as "primary and secondary antisemitism." We wish to make a case, however, for not using the latter terms any more as they give rise to semantically confusing interpretations. ${ }^{4}$ The third variation is Israel-centered antisemitism (IA) which is sometimes described as "new." This manifestation of present-day hatred towards Jews should, however, not be seen as unconnected to the conceptualizations of classical hostility towards Jews.

What in the past had been merely a "felt increase in antisemitism," going along with a growing feeling of uneasiness in Jewish communities, ${ }^{5}$ is now revealed from empirical data of our longitudinal study to be a real increase of hostility towards Jews. There has been a significant increase of verbal antisemitism, both in the virtual world of the internet and in the real world. In fact, both realms of society cannot be separated from each other, one influencing the other in a mutual way. In Germany, for instance, more and more often Jews find themselves subjected to antisemitic harassment, hate speech, or even physical attacks. In Berlin, there had been several cases of Jewish children who were threatened and mobbed by Muslim pupils because of their Jewishness, youngsters wearing a kippah have been attacked. Anti-Israel rallies on German streets go along with hate speech against Jews. The still deep-rooted Judeophobia in the German society shows its ugly face more openly, and the taboo on antisemitism is losing its grip, especially when articulated as anti-Israelism or anti-Zionism.

4 Cf. Schwarz-Friesel and Reinharz, Inside the Antisemitic Mind, 58, 61, 359, n. 43.

5 Cf. A. Zick et al., Jüdische Perspektiven auf Antisemitismus in Deutschland. Ein Studienbericht für den Expertenrat Antisemitismus (Bielefeld: Universität Bielefeld, 2017), accessed September 6, 2017, https://uni-bielefeld.de/ikg/daten/JuPe_Bericht_April2017.pdf. 
Seventy years after Auschwitz, antisemitism has become a very visible and audible threat to Jews and to society, once again.

Although official Germany speaks out against antisemitism, it focuses on right-wing extremists and often leaves aside the fact that antisemitism from the left and the middle of society is by far more dangerous, since it is not as easily recognized and rejected as Jew-hatred. Often, it is accepted as "freedom of

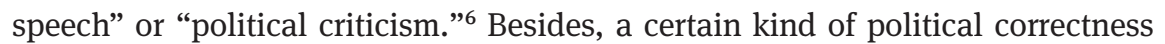
both in the public media and in political communication stands in the way to articulate clearly that there is a severe problem with Muslim antisemitism. In order to avoid strengthening the populistic arguments of right-wing political organizations, mainstream Germany is hesitant to point out to this fierce Jew hatred. Even physical violence towards Jews and Jewish institutions has been frequently reinterpreted as "political indignation." There is a strong tendency to marginalize Muslim antisemitism by explaining it causally as a reaction to Israeli politics. As our data show, however, more than 50 percent of the stereotypes in Muslim discourse are based on classical Jew-hatred. Denial, relativization, and defensive strategies are typical for the modern-day antisemitism of the post-Holocaust phase.

Hence, we notice a severe dissonance in the way in which society handles the problem. There certainly is a strong official condemnation at all levels of the government, when it comes to extreme and coarse antisemitism. At the same time, we notice acceptance and denial of antisemitism when articulated as anti-Israelism or anti-Zionism by educated, non-racist minded people in the German society. Anti-Israelism from Muslim society, at the same time, is defined as "political indignation." The same holds true for the public and media: Empirical research shows an increase of verbal antisemitism, but at the same time, there is rejection of those empirical findings in most of the commentary sections of online press, accompanying the denial/trivialization of the phenomenon, or simply lack of interest. In the commentary sections of the online press, we find a substantial denial of the very existence of contemporary antisemitism. Worse, even in the "expert report" of the German Bundestag, a certain margin-

\footnotetext{
6 Cf. M. Schwarz-Friesel, "Educated Anti-Semitism in the Middle of German Society. Empirical Findings," in Being Jewish in 21st-Century Germany, ed. H. Fireberg and O. Glöckner (Oldenbourg: de Gruyter, 2015), $165-87$.

7 Cf. S. Wildman, "German Court Rules that Firebombing a Synagogue is not anti-Semitic," Vox, January 13, 2017, https://www.vox.com/world/2017/1/13/14268994/synagogue-wuppertal-antisemitism-anti-zionism-anti-israel.
} 
alization of mainstream antisemitism can be noticed, ${ }^{8}$ since most of the empirical research on mainstream antisemitism has simply been ignored.

The political and intellectual fight against antisemitism reveals serious problems. One must get rid of wrong conceptualizations and frameworks. The position here adopted is that antisemitism is no social prejudice system; it is not necessarily connected racism; it is not a bias against a certain minority; it is not necessarily related to some form of anti-modernism. It is a cultural category deeply embedded in collective memory. Antisemitism 2.0 makes this transparent: The age-old resentment is expressed in multiple modern forms but essentially is the same at its core. Yet, the web and its online communication has brought a new enhancement of Jew-hatred. ${ }^{9}$

In order to understand why the internet plays such a significant role in the increase and spreading of antisemitism, pushing forward the normalization of antisemitic communication at the same time, we should first consider the main features of the online communication.

\section{The Relevance of the Internet: The Web 2.0 as "the Fifth Power" in Society}

Web 2.0 is the primary multiplier and place for the transmission of manifestations of antisemitism. Expressions of antisemitic sentiment have increased significantly in the digital age. ${ }^{10}$

Through the social web, communication and persuasion have changed in a way and to an extent that has never been seen in history. The term Web 2.0 was coined around 2004, since changes in technology created a kind of internet adapting to new possibilities of information processing. The use of online social networking has led to a new web communication. Antisemitism 2.0 is determined by increasingly effective ways of promoting Judeophobic thinking and

8 Cf. Unabhängiger Expertenkreis Antisemitismus, "Bericht des Unabhängigen Expertenkreises Antisemitismus,” issued April 7, 2017, http://dip21.bundestag.de/dip21/btd/18/119/1811970.pdf.

9 Cf. M. Weitzman, "The Internet is Our Sword: Aspects of Online Antisemitism," in Remembering for the Future: The Holocaust in an Age of Genocide, ed. J. K. Roth and E. Maxwell-Meynard (New York: Palgrave, 2001), 925-91; A. Foxman and C. Wolf, eds. Viral Hate: Containing Its Spread on the Internet (New York: Palgrave Macmillan, 2013); R. Cohen-Almagor, Confronting the Internet's Dark Side: Moral and Social Responsibility on the Free Highway (New York: Cambridge University Press, 2015).

10 Cf. Schwarz-Friesel, “Antisemitism 2.0.” 
its social acceptance. ${ }^{11}$ The Web 2.0 is all about the sharing of information: therefore, it is often referred to as the "interactive web" or the "social web," since Web 2.0 sites are content driven, and a central feature of the web-based interaction is the user-generated content, going along with high speed, global accessibility, and interconnectivity. Social media has become the most important information resource in a broad sense: it means expressing attitudes, communicating feelings, sharing values, all of which together creates mental belief systems. The online processing and interaction of data and information make increased use of multiple semiotic modes: it is multimedia, multichannel, and multimodal which increases its persuasive power. ${ }^{12}$ Since often the information processing is anonymous, it has no taboos, no restricting forces, and is not encumbered by political correctness.

The Web 2.0 influences and shapes every aspect of our social life more than any other modern technology, cultural achievement, or social development and plays a significant role in meaning making and in interpersonal bonding. It is presently recognized that the internet and especially social media have become the most important tool that enables the sharing of ideas around the world, that transcend all boundaries. ${ }^{13}$ It enhances the sharing of information quickly and effectively and brings about the development of online communities. This is why the internet has been frequently called the "fifth power in society."

The following questions deserve attention: How is antisemitism coded and encoded in the web? In what way do specific features of the internet affect and enhance the spreading of antisemitic content? Recognizing the impact of the internet on present-day society and everyday life, how should we describe the symbiosis of the virtual and the real world?

11 Cf. P. Iganski and A. Sweiry, "Antisemitism on Social Media," Lecture for the Panel Internet and Antisemitism, Conference "An End to Antisemitism!", University of Vienna, Vienna, February 21, 2018.

12 Cf. M. Zappavigna, Discourse of Twitter and Social Media: How We Use Language to Create Affiliation on the Web (London: Bloomsbury, 2012).

13 Cf. Reuters Institute, Digital News Report 2017, accessed June 10, 2018, http://www.digital newsreport.org/survey/2017/overview-key-findings-2017. 


\section{Research Methods and Corpus Studies: Towards more Authenticity}

When it comes to antisemitism research, often the methodological part is hardly mentioned although it is of high relevance: How can Jew-hatred be measured empirically? What data are valuable and reliable in order to understand and to explain antisemitism as a mental and communicative phenomenon?

A much used tool employed by researchers in sociology and political science are polls or attitude surveys. However, that method is unsatisfactory, due to the formulation of the questions asked (that might trigger priming effects), or the situation in which persons are approached, or the inhibitions people have when dealing with the theme "antisemitism" (leaving aside the fact that even in anonymous polls people tend to stick to political correctness). A much better method to capture and to explain antisemitic utterances and their underlying attitudes are corpus studies, which rely on natural data typical of a certain discourse domain and use a great amount of texts that are produced naturally. ${ }^{14}$ Corpus analysis provides a method that is based on naturally produced utterances, and hence more reliable, as an authentic source of attitudes about Jews, Judaism, and Israel. Relying on the assumption within cognitive science that verbal utterances are traces of the mental activity of its producers, this data is much more realistic, since authentic language data gives insights into antisemitic thinking and feelings of people and provides the possibility of exploring and understanding the social contexts within which antisemitic discourse takes place.

The Web 2.0 provides a huge reservoir for the research of everyday verbal antisemitism with corpus studies. Social media, especially, offers a wide range of natural data and hence a more reliable source of attitudes about Jews. Nevertheless, despite their potential, there has been little systematic content analysis of antisemitic discourse found in social media. ${ }^{15}$

In our project, firstly we constructed a software crawler that was able to draw a huge amount of texts from internet communication with the help of certain key words like Jews, Judaism, Israel. The data (more than 250,000 texts from the Web) were collected and stored, while kept in their original settings. From those texts, subcorpora, then, were analyzed both quantitatively and qualitative-

14 Cf. Schwarz-Friesel and Reinharz, Inside the Antisemitic Mind, $326 \mathrm{ff}$.

15 Cf. P. Iganski and A. Sweiry, "Antisemitism on Social Media"; A. Oboler, "Solving Antisemitic Hate Speech in Social Media through a Global Approach to Local Action," Lecture for the Panel Internet and Antisemitism, Conference “An End to Antisemitism!”, University of Vienna, Vienna, February 22, 2018. 
ly with MAXQDA. Using data from different types of texts, the present article shows the wide range of antisemitic communication, examples including cartoons, Facebook posts, blogs, texts from Twitter, YouTube Video comments and contributions to discussion forums and online media on various web sites. Diverse political orientations were observed, all of which illustrates and explains the main conceptual features of contemporary Jew-hatred: Antisemitism 2.0, although new in its form and processing, rests on the age-old Judeophobic image of an omnipresent evil force that needs to be defeated for the sake of humanity and world peace. The conceptualization of The Eternal Jew is prevalent in all communication areas of the social media. It is important to emphasize that although various manifestations of antisemitisms do exist-of the right, the left, racist, economic, cultural, religious, explicit, or coded-they are always based on the same age-old hostility influenced by stereotypes engraved in collective consciousness and stored in cultural memory as verbal patterns.

\section{Antisemitism in the Web: The "Dark Net" of Right-Wing Extremists}

Of course, we do find a lot of aggressive and vulgar antisemitism uttered by the political far-right. This form of antisemitism has a repulsive face, shown in utterances such as: "ugly mean Jews, mankind's rats, one should kill by gas all of them [...] Jewish criminals in rascist Usrael (sic!)."16

Jew-hatred of that kind is found on diverse internet platforms, blogs, and home pages. One of the oldest and well-known right-wing antisemitic sites in the USA is the Jew Watch website, based on the conceptualization of the eternal greedy Jew wanting to dominate the world. They, too, have a website informing about Jew Watch:

Jew Watch [...] by Frank Weltner, a brave man who simply wants to spread the truth. Jew Watch has factual evidence of thousands of atrocities committed by filthy kikes, [...] Jews, as we all know, have total control over almost all the information in the world. ${ }^{17}$

16 The original commentary on YouTube reads: "die miesen hässlichen Juden, Ratten der Menschheit, man sollte alle [...] Judenverbrecher im rassitischen Usrael (sic!) vergasen.” Commentary on YouTube, July 2014, accessed February 2, 2018. Translation by the author of this article.

17 https://encyclopediadramatica.rs/Jew_Watch, last accessed February 2, 2018. 
Jew Watch contains a huge amount of classical right-wing propaganda. It promotes Holocaust denial and various accusations against "Jews involved in crimes." In 2004, it was reported that if one is interested in the question "What is a Jew?" and tried to find out from a Google search, the first of 1.75 million entries that appear when typing "Jew" into the search engine had been Jew Watch. Therefore, a petition was started in order to demand that Google remove this hate site "Remove Jew Watch-." Yet, the content of this page can still be easily accessed with no effort. After only three clicks on Google, one sees a Wikipedia page that promotes and praises Jew Watch. Here, it is worth noting the statement "who simply wants to spread the truth" since this argumentation has a long tradition in antisemitic discourse and is used to justify any antisemitic claims that have no root in facts. Clinging to the truth value of even the most absurd accusations (such as the blood libel claim) is typical of Judeophobic communication along the ages. ${ }^{18}$

A crude fantasy frequently found in right-wing circles employs the name "Rothschild" as a figure for the concept of a Jewish conspiracy to rule or wanting to rule the world. The following post with a blurred face of Rothschild can be found on different and multiple Facebook pages:

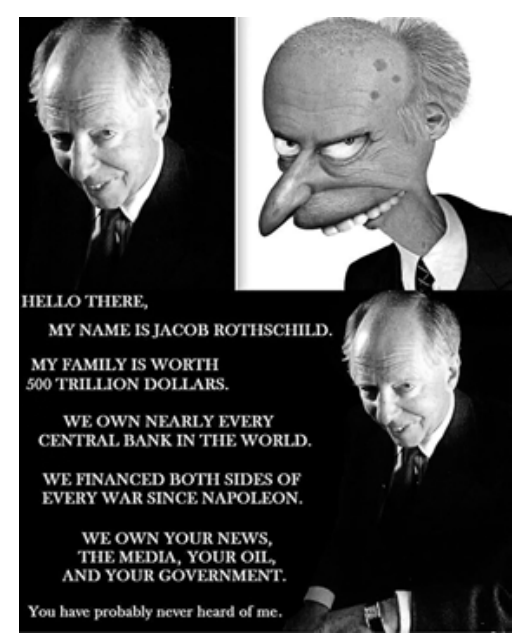

Figure 1. "Hello there, my Name is Jacob Rothschild." Accessed June 10, 2018, https:// imgur.com/gallery/M5pH0.

In this example, one sees the symbiosis of multimodal information coding pictures with text stressing Jewish international domination.

18 See also J. Trachtenberg, The Devil and the Jews: The Medieval Conception of the Jew and its Relation to Modern Antisemitism (New Haven: Yale University Press, 1943). 
The next example is a picture from a Twitter account. It depicts an open oven with money notes lying around. The implication is that if enough money will be deposited into the oven, the Jews will even crawl into the gas oven-a bizarre manifestation of the classical stereotype of "Jewish greediness." This picture has been posted on many Twitter accounts world wide and is visible up to this very moment. ${ }^{19}$

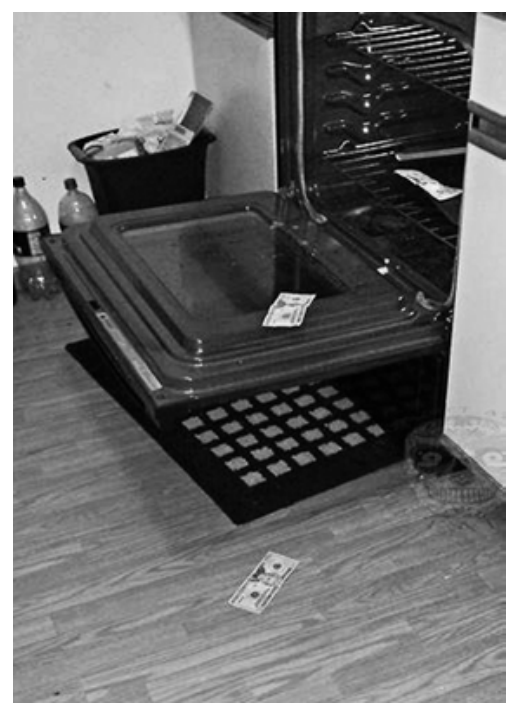

Figure 2. “Ловим еврея [We are catching a Jew]." Accessed June 10, 2018, https://pikabu.ru/story/ lovim_evreya_1484475.

The overt, vulgar, and aggressive Jew-hatred expressed by the far-right and by neo-Nazis certainly deserves attention, and its danger should not be ignored. Nevertheless, these primitive texts are not the kind of antisemitisms with the highest influential impact and persuasion on the web. In fact, the "dark net" pages of right-wing extremists are a rather minor part of Antisemitism 2.0 and certainly not the most dangerous ones, since many mainstream users are repelled or bored by such primitive messages.

\section{Conspiracy Phantasies: Open Access}

The mainstream webpages accesses by normal everyday users represent a much more worrying phenomenon. It is important to point out that that conspiracy

19 Cf. https://twitter.com/mattkatz00/status/740697293507166208, accessed June 10, 2018. 
phantasies about Jewish world domination and the evil nature of the Jews are frequently found also in daily mainstream commentary sections, e.g., in YouTube commentary sections below new films and old movies from Nazi propaganda. Crude conspiracy phantasies are also "open access" on the Amazon book store or Hugendubel.de, booklooker.de, or Google.books on the internet: e.g., the Tilman Knechtel book from 2015, Die Rothschilds: Eine Familie beherrscht die Welt, combines on its cover page in a multimodal form a dramatic picture and a sensational verbal text to convey the age-old conspiracy fantasy of Jewish world domination stemming from the Rothschild family with its connections to Israel. The jacket blurb reads: "Incredible, but true: There is a hidden mighty power on this planet that turns the wheel around [...] Find out about the tricks [...] of the Rothschilds. The blood of all great wars is on their hands [...] Yet, their thirst for blood has not been satisfied [...] Their goal is a third world war that destroys everything, and a government, controlled from Jerusalem." ${ }^{20}$ It is claimed that "far off from adventurous conspiracy theories, the net of the Rothschilds is identified," "whose power is wrapped around the globe like octopus arms." ${ }^{21}$ Although the text follows the classical pattern of crude conspiracy phantasies and depicts several Judeophobic stereotypes and metaphors, it is posted on all online bookseller stores and can be purchased freely-without any warning remark from the booksellers.

Overall, the concept of an almighty world ruling Rothschild family remains a classical theme for Jew-haters up to our own time. Below the film "Die Rothschilds" (a Nazi Propaganda movie from 1940) found on YouTube frequently, there are comments such as "Jews are [...] a barbaric people"22 or: "I agree the Rothschild family is the major root of evil in this world."23

Online comments, together with frequently posted rap songs that find millions of followers on the web, ${ }^{24}$ webpages such as "Anonymous" and even academic books (such as the much referred to book The Israel Lobby, ${ }^{25}$ whose au-

20 https://www.amazon.com/Die-Rothschilds/dp/3941956213, accessed June 10, 2018. Translation by the author of this article.

21 Ibid.

22 Commentary on YouTube, accessed January 14, 2018.

23 Commentary on YouTube, accessed January 3, 2018.

24 Cf. M. Eddy and A. Marshall, "Unwelcome Sound on Germany's Stages: Musicians Who Boycott Israel,” The New York Times, July 1, 2018, https://www.nytimes.com/2018/07/01/arts/music/ bds-germany-young-fathers.html.

25 Cf. J. Mearsheimer and S. M. Walt, The Israel Lobby and U.S. Foreign Policy (New York: Farrar, Straus and Giroux, 2007). 


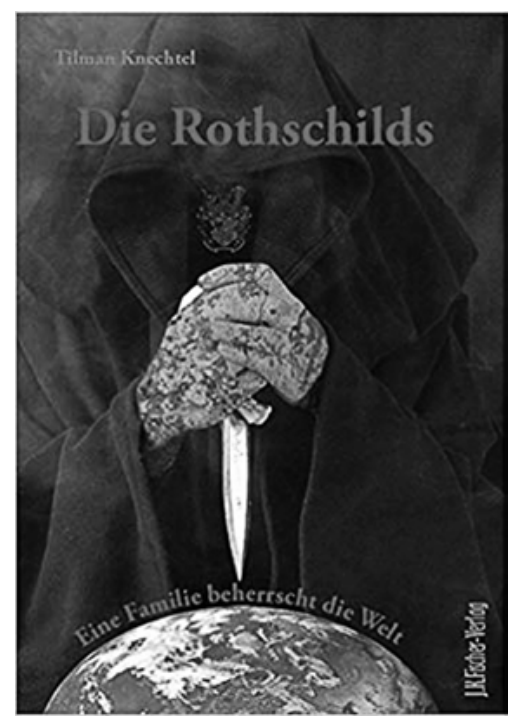

Figure 3. Tilman Knechtel. Die Rothschilds: Eine Familie beherrscht die Welt. Gelnhausen: J.K.

Fischer Verlag, 2015.

thors, incidentally, deny any anti-Israeli intention) make the notion of a Jewish control acceptable to the social mainstream.

\section{The Real World: No Big Difference Compared with the Virtual Reality of the Web}

The belief in Jewish or Zionist inherent evil and in the Jews' alien nature is not only found in the virtual world of the Web 2.0. Also, in the real world, classical anti-Jewish or anti-Israel stereotypes determine thinking and believing of many people from different social strata:

"Jews controlling the media, economy, government, and other societal institutions, [...] I think, [this] is not antisemitism," pronounced by a student senator at Stanford University in April 2016, claiming that the concept of an overall Jewish domination is not a stereotype but a fact. ${ }^{26}$ And a cabaret singer posted in February 2018 a song about the mean and evil forces in the world, claiming

26 Y. Rosenberg, "Stanford Student Senator: Saying 'Jews Control the Media, Economy, Government' is 'Not Anti-Semitism,”” Tablet Magazine, April 7, 2016, https://www.tabletmag.com/scroll/ 199362/stanford-student-senator-saying-jews-control-the-media-economy-government-is-notanti-semitism. 
that: "The world gets meaner day by day [...] Why? [...] who asks for the names and the sins [...] of Rothschild, Soros and com [...] greedy bankers [...] they buy the world, they tear down the world." ${ }^{27}$ Subsequent comments on YouTube declared: "All respect, thank you [...]." Criticized for uttering such antisemitic views, the singer declared that she was merely expressing disapproval for certain ongoing processes. ${ }^{28}$ Rap songs commonly and frequently distribute anti-Jewish phantasies, surrealistic pictures of a struggle for the good, and a world peace without Jews. ${ }^{29}$ The German musical industry officials awarded-in spite of vehement protesting - the Echo prize to two rappers calling their music "art and freedom of expression," although the texts contained lines mocking Auschwitz victims and coding classical anti-Jewish stereotypes. ${ }^{30}$ The nomination and award shows that evaluations on the web go along with processes in the real world. Only after a wave of protest coupled with a TV documentary uncovering the antisemitic nature of many rap songs, ${ }^{31}$ the Echo nomination process broke down. Some short time later, however, prosecutors in Germany came to the conclusion that there was no clear evidence for spreading antisemitic content in the songs. Even a text such as "Make another holocaust again, come on with the Molotov"32 conveying Holocaust marginalization and implying a call to violence, was considered to be "artistic freedom." 33

27 Lisa Fitz, "Ich sehe was, was du nicht siehst!” video, 5:18, https://www.youtube.com/watch? $\mathrm{v}=0 \mathrm{tCNhdUqZJo}$.

28 Cf. "Der ganze Liedtext ist voll von Codes," welt.de, January 31, 2018, https://www.welt.de/ vermischtes/article173042642/Lisa-Fitz-bedient-mit-YouTube-Song-antisemitische-Verschwoer ungstheorien.html.

29 Cf. also J. Rathje, "Antisemitism in Post-Holocaust Conspiracy Ideologies," Lecture for the Panel Internet and Antisemitism, Conference "An End to Antisemitism!”, University of Vienna, Vienna, February 21, 2018.

30 Cf. e.g. K. Belihart, "Wie antisemitisch sind Kollegah und Farid Bang?” Frankfurter Allgemeine Zeitung, April 3, 2018, https://www.faz.net/aktuell/feuilleton/pop/antisemitismus-vor wuerfe-gegen-echo-nominierte-15524595.html; M. Eddy and A. Curry, "Fury in Germany as Rap Duo With Anti-Jewish Lyrics Gets Award," The New York Times, April 18, 2018, https://www. nytimes.com/2018/04/18/arts/music/anti-semitism-german-rap.html.

31 "Die dunkle Seite des Deutschen Raps," TV documentation by Viola Funk, accessed June 10 2018, https://www1.wdr.de/mediathek/video/sendungen/die-story/video-die-dunkle-seite-desdeutschen-rap-100.html.

32 The original German text goes "Mache wieder mal 'nen Holocaust, komm' an mit dem Molotow." Translation by the author of this article.

33 Bundesverband Musikindustrie, "Presseinformation: Zur Diskussion um das Album "JBG3" von Kollegah \& Farid Bang sowie zum Beschluss des ECHO-Beirats,” issued April 6, 2018, accessed June 10, 2018, http://www.echopop.de/fileadmin/echopop/upload/news/2018/Press einformation_zur_Diskussion_um_das_Album_JBG3_und_zum_Beiratsbeschluss.pdf. 
At the same time, for the last fifteen years or so, we witness to the rise and increase of a so-called "new antisemitism" (that proves to be not new at all but rests on the age-old Jew hatred just coming along in the new garb of anti-Zionism), originating mostly from Leftist circles and disguised as "criticism against Israel." This Israel-related antisemitism is today a prevalent manifestation of Jew-hatred, and its massive spread on social media is a worrying trend. It also articulates itself in the boycott movement against Israel, Boycott, Divestment, and Sanctions (BDS), invented by Palestinians, strongly supported by the Left, where diverse antisemitic positions combine with a fierce and obsessive antiZionism. A typical expression of that new trend were the wide attacks against the science fiction movie Wonder Woman, featuring the Israeli actress Gal Gadot: Users on Twitter criticized the actress for being an Israeli "Zionist" and a "child murderer" because she served in the Israeli defense forces. With Lebanon banning the movie, a state took part in this campaign, among the propagators such prominent figures as the cartoonist Carlos Lakuff who re-posted a tweet calling Gal Gadot to be an "genocide enthusiast."34

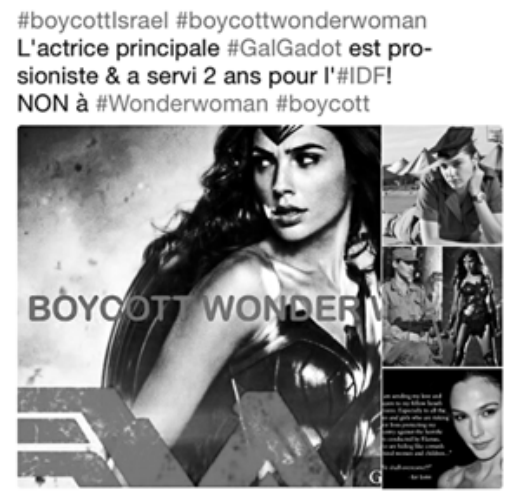

Figure 4. Gal Gadot boycotted for her role in Wonder Woman on the basis of her Israeli nationality and serving the IDF. https://twitter. com/zionocracy/status/869528564542066689, accessed June 10, 2018.

Calls to boycott the movie were expressed in Twitter comments to the image shown above from all over the world: "She supports Zionist terrorist Nazi Israeli occupation forces, she is racist, fascist, [...] insane.” (Afghanistan); “Zionist racist who cheers openly as children are killed \& promotes the genocide of Palestine, [she] is an appalling example of the human race to present to our growing kids" (Great Britain); "all Israelis are racists and murders" (California); "ISRAHEILL CRIMINEL! ISRAÉLIENS ASSASSINS!” (France); "because Zionism is the biggest threat to our common humanity!" (British Columbia); "to destroy the

34 https://twitter.com/latuffcartoons/status/871651516423262208, accessed June 10, 2018. 
Zionists from the face of the earth" (India). ${ }^{35}$ Those tweets coded a fierce anti-Israelism based on antisemitic stereotypes.

And there is hardly any difference in the real world: In 2014, the union in Europe National Union of Teachers (NUT) passed a resolution backing a boycott of companies trading with Israel. ${ }^{36}$ In 2016, University College London Union (UCLU) voted to support the BDS campaign. ${ }^{37}$ In the same year, the University of Manchester's student union adopted BDS motions. On April 5 2018, the Union of Students in Ireland voted to join the BDS campaign against Israel, after the country's largest teachers' union articulated its support for the movement. ${ }^{38}$ In Europe, the UK BDS movement is visible everywhere, and the Labour leader Corbyn is well known for his outspoken anti-Israelism.

So far, there have been innumerable incidents of BDS activists standing in front of supermarkets calling for a boycott of Israeli fruits or disturbing Israeli workshops. In Berlin, during a presentation at the Humboldt University in July 2017, BDS activists stormed a lecture by a member of the Knesset calling her a child murderer. Not willing or able to keep up some argumentation, the action consisted of shouting and cursing and did not allow a discussion to take place. There were hysterical screams such as "the blood of the Gaza Strip is on your hands" or "apartheid Israel." ${ }^{39}$ Note that all those allegations are found in thousands on the web. An eighty-two-year old Holocaust survivor who participated in the delegation who had visited the library square of the university, where in 1933 German students and lecturers burned tens of thousands of books of Jews and opponents of the Nazi regime, was shouted down by BDS activist for coming from the "wrong country." Incidents like those reveal the closed mind, the indoctrination, the obsessive nature of those activists, and total lack of empathy with Holocaust victims. BDS uses any opportunity to harm Israel no

35 https://www.thepetitionsite.com/de/572/108/486/boycott-wonder-woman-movie/, accessed June 10, 2018.

36 Cf. "Europe’s Largest Teachers' Union Endorses Israel Boycott Call," Middle East Monitor, May 3, 2014, https://www.middleeastmonitor.com/20140503-europes-largest-teachers-union-en dorses-israel-boycott-call/.

37 University College London Union, "Union Policy UP1514: Motion: In support of BDS at UCLU,” issued March 7, 2018, https://studentsunionucl.org/sites/uclu.org/files/policies/up1514. pdf.

38 Cf. "The Union of Students in Ireland Votes to Support BDS," The Palestine Chronicle, April 5, 2018, http://www.palestinechronicle.com/union-students-ireland-votes-support-bds/.

39 G. Lehrke, "Eklat an Humboldt-Uni Knesset-Abgeordnete bei Podiumsgespräch niedergebrüllt,” Berliner Zeitung, June 22, 2017, https://www.berliner-zeitung.de/berlin/eklat-an-hum boldt-uni-knesset-abgeordnete-bei-podiumsgespraech-niedergebruellt-27845640. 
matter how simple, naïve and banal the event is: even the funny Song Contest ESC 2018 was instrumentalized to delegitimize the Jewish state. ${ }^{40}$

Thus, the only difference between antisemitism online and antisemitism in the real world is that its dissemination online is much more widespread and more easily accessible. You will find a wave of thousands of texts spreading within seconds or minutes within the virtual world. While the violence of antisemitism 2.0 is on the verbal level, the real world shows physical violence against Jews, as well. However, we should not underestimate the persuasive power of death threats, the coding of stereotype, and the spreading of crude phantasies. Beneath the verbal threats and abuses, the linguistic brutality and conceptual hatred lies a powder keg with the potential to explode any time in the real world. Thus, verbal violence, and the rhetoric of hate speech against Jews should be seen as a very dangerous phenomenon.

\section{Accessibility and Omnipresence: "Antisemitism with one Click"}

One of the most worrying features of the presence of antisemitisms on the internet is the ease with which they are reached and disseminated. A person may search for information about certain themes related to Jews and get instead antisemitic indoctrination. If one uses certain keywords, such as the Jewish holiday Purim, or terms like Jews, Judaism, after one or two clicks on Google, one accesses antisemitic webpages or blogs. There are innumerable pages like Electronic Intifada ${ }^{41}$ or Christianity Beliefs ${ }^{42}$ that share posts and the most surrealistic allegations against Israel, as well. Further, there is a veritable infiltration of everyday topics (e.g., "Birds in Israel," or Star Wars-SciFi fan forum ${ }^{43}$ ) with antisemitic content, expressed as Holocaust relativization, Nazi-comparisons, denial of guilt, refusal of remembrance culture, or Judeophobic stereotypes (e.g., Jews are vengeful, cruel).

40 Cf. "Eurovision Boycott of Israel-ZERO Points to the Song of Israeli Apartheid," Facebook page, accessed June 10, 2018, https://www.facebook.com/Zero.Points.To.Israeli.Apartheid/.

41 Cf. https://electronicintifada.net/, accessed February 2, 2018.

42 Cf. http://christianitybeliefs.org/end-times-deceptions/christians-should-not-support-israel/, accessed February 2, 2018.

43 Cf. http://www.projektstarwars.de/forum/sonstige-umfragen/32261-schlussstrich-nazi-ver gangenheit-2.html, accessed February 2, 2018. 
Typical for internet communication is that a normal user by now finds antisemitic utterances everywhere, even in campaigns aiming to combat it. ${ }^{44}$ For instance, during the Gaza conflict in 2014, the German journal BILD initiated a campaign against antisemitism, thus reacting to the strong Jew- and Israel-hatred seen and heard on German streets and in recurrent anti-Israel demonstrations. ${ }^{45}$ Among Twitter texts calling people to join a demonstration against antisemitism at the Brandenburg Gate in Berlin, there were also many tweets such as: "End the Zionist occupation! Stop the Jewish terror and the brutal apartheid regime in unjust state Israel." ${ }^{46}$ Another commentary read "Why 'Never-againhatred-against-Jews'? It's all about the land robbery by the Zionists!"47 In 2018, when the Jewish community made a solidarity call "Berlin trägt Kippa" ("Berlin wears a kippah"), after a young man had been attacked physically on the street, the same phenomenon could be observed: Many of the tweets within this context were repugnant and revealed both denial of antisemitism and at same time the coding of Judeophobic stereotypes and hatred against Israel. ${ }^{48}$ This kind of infiltration of verbal antisemitism within texts that are intended to combat that very phenomenon enhances and very much intensifies the omnipresence of Judeophobic belief systems.

\section{Re- or De-contextualizing Antisemitic Content: Echo Chambers}

A phenomenon frequently found on the internet is the so-called echo chamber effect. An echo chamber on the web means a discourse situation in which attitudes are reinforced by communication and repetition inside a closed communication system. Webpages of BDS or the page of Anonymous (that is mainly fo-

44 Cf. Schwarz-Friesel, “Antisemitism 2.0.”

45 Cf. "Stimme erheben: Nie wieder Judenhass!” Bild Zeitung, July 25, 2014, https://www.bild. de/politik/inland/antisemitismus/nie-wieder-judenhass-36968206.bild.html.

46 "Beendet die zionistische Besetzung! Stoppt den jüdischen Terror und das brutale Apartheidsregime im Unrechtsstaat Israel,” Twitter commentary on \#niewiederjudenhass BILD campaign, July 2014, issued September 14, 2014. Translation by the author of this article.

47 "Wieso \#niewiederjudenhass ? Es geht um den Landsraub durch Zionisten!” Twitter commentary on \#niewiederjudenhass BILD campaign, July 2014, issued September 14, 2014. Translation by the author of this article.

48 Cf. e.g. J. Demnitz, "Solidaritätskundgebung 'Berlin trägt Kippa': 'Heute hat sich etwas verändert',” Der Tagesspiegel, April 25, 2018, https://www.tagesspiegel.de/berlin/solid aritaetskundgebung-berlin-traegt-kippa-heute-hat-sich-etwas-veraendert/21215618.html. 
cused on conspiracy phantasies), for example, depict all typical features of an echo chamber. It means that users prefer to stay in communication fields that articulate their own world views and those attitudes alone. Hence, people are able to seek out information which reinforces their existing views. They will not be confronted with controversial arguments that would challenge their fixed beliefs. With regard to antisemitism, in that way it is strengthened through the homogenizing effect. Within echo chambers, re- and de-contextualizing information plays an important role. It means to put information from one source into another, creating a situation in which attitudes are enhanced by repetition, omitting the original contextual information.

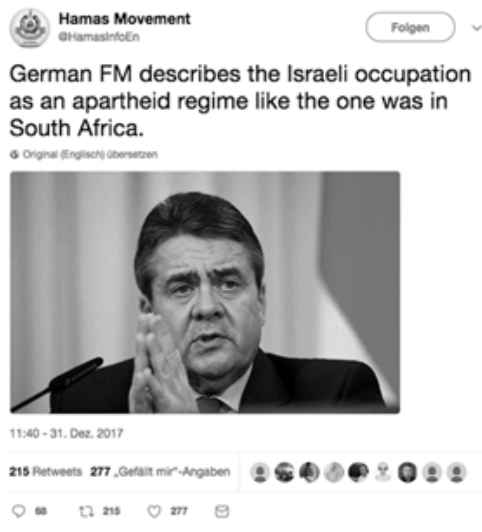

Figure 5. German former foreign minister Sigmar Gabriel on Hamas' Twitter account. https://twitter. com/hamasinfoen?lang=de (official account of Hamas Movement-picture deleted in the meantime)

On the Hamas account, for instance, an utterance of former German Foreign minister Gabriel had been posted to delegitimize the state of Israel. In this recontextualization process, the text, containing an apartheid analogy, is extracted from its original context (de-contextualization) and put into another context in order to strengthen and to legitimize the anti-Israel attitude of Hamas. This recontextualization has a high persuasive potential implying that the minister of Germany supports the view of Hamas. ${ }^{49}$

49 After his visit to Hebron in 2012, then German foreign minister Gabriel had called Israel's politics an "apartheid regime" with a legal vacuum for the Palestinians. While Gabriel has revoked his statement in its drastic form and has repeatedly called himself a friend of Israel, he still criticizes Israel's settlement policy in the West Bank and Gaza. Cf. e. g. "SPD-Chef kritisiert israelische Siedlungspolitik,” Süddeutsche Zeitung, March 19, 2012, https://www.sueddeut sche.de/politik/kritik-an-siedlungspolitik-spd-chef-nennt-israel-apartheid-regime-1.1309595. In 2017, Gabriel referred back to his statement from 2012 while speaking about the rising Muslim antisemitism in Germany in Berlin. The Hamas tweet reacts to Gabriel's exemplary usage of 
Equally dominant, both in the virtual and the real world, is a conceptual symbiosis of the semantics of Israelization and classical Judeophobic stereotypes. Typical is the trivialization of the Holocaust, brought in connection with the Palestinian-Israel conflict. "How dare you raise the issue of antisemitism when so many people are being killed!”-utterances like this have been frequently posted during the Gaza conflict. The use of symbolism related to the Nazis is used not only to attack Israel and Jews but also to invert the Holocaust. This creates false comparisons that trivialize the Holocaust and misinform those not familiar with the historical facts. A recurrent accusation is that Israel is behaving towards the Palestinians as the Nazis did to the Jews. ${ }^{50}$

\section{Mainstream Antisemitism}

Empirical research shows that the main multipliers and propagators of presentday antisemitism are the mainstream web sites.

"Why are Jews always so mean?" is a question asked implying that Jews are indeed mean and vile creatures. ${ }^{51}$ For seven years now, this "good question" can be seen on this platform, because the net supporters claim that this an "interesting question" and so far have not eradicated it.

Another typical example of how Antisemitism 2.0 is distributed on mainstream websites comes from an online homepage-platform: "The Jews cause only TROUBLE and occupy a land that does not belong to them and kill women and children and show no remorse [...] Such are the Jews [...] This is the TRUTH." 52 This text has not been deleted either. Remarks of such kind remain online for a long time and help to "normalize" antisemitism in the internet and in society, especially among youngsters.

his own statement in this context. Cf. "Sigmar Gabriel, die Apartheid und ein Lob von der Hamas," Audiatur Online, January 4, 2018, https://www.audiatur-online.ch/2018/01/04/sigmargabriel-die-apartheid-und-ein-lob-von-der-hamas/.

50 Cf. Schwarz-Friesel and Reinharz, Inside the Antisemitic Mind.

51 “Wieso sind Juden immer so böse?” Question by user MissSchool, gutefrage.net, issued January 1, 2011, accessed January 11, 2018.

52 "Juden machen nur STRESS und besetzen ein Land das denen nicht gehört und töten Frauen und Kinder und zeigen keine Reue [...] Das sind Juden [...] das ist die WAHRHEIT" hausaufgaben.de, issued June 4, 2008, accessed February 1, 2018. Translation by the author of this article. 


\section{Combination of Classical and Israel-related Stereotypes $^{53}$}

As we have already pointed out, one of the dominant versions of antisemitism, which has severely intensified in the last few decades, targets Israel, the Jewish state. Its perpetrators often call themselves anti-Zionists. They aim to isolate Israel and portray it in gloomy pictures. Calls for the elimination of Israel are among the most frequent expressions of this position. Israeli steps against terrorism or Israeli military actions are frequently compared with the Nazi extermination of the Jews, equating Israel with genocidal murder in an analogy that is deliberately antisemitic. Nevertheless, the Middle East conflict between Israel and the Palestinians is not the cause but only one trigger among many for presentday Jew-hatred. It is a common feature of contemporary antisemitism in which classical and Israel-related stereotypes mingle and are combined in antisemitic utterances. ${ }^{54}$ Deeply rooted Judeophobia showed up in debate that broke out in Germany in 2012 on the issue of circumcision, where classical antisemitic patterns emerged: "Unchristian madness, religious delusion, barbarian ritual, dubious rites of a backward religion, children mutilation of a sect, crimes against children by an atavistic religion, the rites of tribes form the bronze age, perverse torturers of babies. ${ }^{~} 55$

Although the topic "circumcision" had nothing to do with the Middle East conflict, there were recurrent references to Israel in internet comments such as "Who mutilates his own children, easily kills Palestinian kids, too."

The same holds true for the analysis of web comments on the speech given by Josef Schuster, the president of the Central council of the Jews in Germany, on immigration in 2015: Although neither Israel nor the Middle East conflict were the topic of his talk, 23 percent of the commentaries on it contained references to Israel. In multiple stereotype encodings, 42 percent of the comments displayed

53 All examples and figures given in this paragraph are drawn from Schwarz-Friesel, "Antisemitismus 2.0.” The results of this longitudinal study were published in July 2018.

54 Cf. Schwarz-Friesel and Reinharz, Inside the Antisemitic Mind and Schwarz-Friesel, "Educated Anti-Semitism."

55 These examples are taken from various commentaries on platforms such as Facebook and YouTube but also from discussion forums of various newspapers, magazines, and broadcasting companies such as Fokus, Spiegel, ARD, and ZDF. The originals read "Unchristlicher Irrsinn, religiöser Wahn, barbarisches Ritual, dubiose Riten einer rückständigen Religion, Kinderverstümmelung einer führenden Sekte, Kindsverbrechen einer antiquierten Religion, die Riten bronzezeitlicher Stämme, perverse Säuglingsfolter.” Translation by the author of this article. 
Israel-related stereotypes going along with the coding of 57 percent classical stereotypes.

An extensive corpus study of more than 2,000 social media posts during the 2014 Gaza conflict displayed an amount of 46 percent Israel-related stereotypes, 40 percent classical (traditional) stereotypes, and 13 percent post-Holocaust concepts. The combination of classical and Israel-related stereotypes was found in more than 20 percent of the texts, whereas the symbiosis of post-Holocaust and Israel was found in merely 10 percent of the comments. This result points out that the age-old resentment is very much alive and still working on the collective mind. To understand the persistence of this classical Jew-hatred, one has to go back to its origins.

\section{The Continuity of the Concept of the "Eternal Evil Jew": Along the Ages, never at the Edges of Society}

For millennia, Jews have been demonized, defined as the source of all evil and as the enemies of humankind. This is the root of the irrational hatred ${ }^{56}$ against Jews and the legitimization of the wish to eradicate them. On the web, this concept is articulated in utterances such as: "Jews are the enemy to all mankind"; "Israel is the filth of the world!"; "Jews are the evil of mankind and threaten world peace"; "Israel is an illegitimate evil state and threatens world peace." 57 The beginnings of this rhetoric are found 2,000 years ago, at the time of the separation between Christianity and Judaism and the condemnation of the Jews, that became part of the developing Christian creed. ${ }^{58}$ This metaphysical belief, fed throughout the centuries also by a variety of additional factors, culminated in the Holocaust, and expressed the belief that the Jews have to vanish from the earth for the good of humankind. A similar concept is presently applied to Israel, aiming at its elimination as a Jewish state.

Anti-Jewish thinking and feeling represents a cultural category stored in the collective memory of Western society, constantly re-activated and kept alive for

56 With a mean value of 70 percent, hatred is the most commonly encoded emotion on the web. Cf. Schwarz-Friesel, “Antisemitismus 2.0.,” Pt. 8.

57 These are all commentaries found on YouTube, accessed January 15, 2018.

58 Cf. M. Simon, Versus Israel: A Study of the Relations between Christians and Jews in the Roman Empire AD 135-425 (Oxford: University Press, 1996) and the contribution by A. Lange and M. Grossman in this volume, 133-64. 
2,000 years through language, as the following examples from the last 500 years clearly show: "blood-thirsty dogs and murderers [...]” (Martin Luther, 1543); “[...] godless, wicked, thieving, predatory and murderous Jews” (Georg Nigrinus, 1570); "like cancer [...]" (Rechtanus, 1606); "the most despicable people on earth"; "enemy of all mankind" (Voltaire, 1761, 1764); "In the middle of excrement" (Georg Wilhelm Friedrich Hegel, 1800); "ugly dirty faces [...] cruel" (Charles Dickens, 1839); "fat, rich, horrifying” (Oscar Wilde, 1891); "Human disease” (Jakob Friedrich Fries, 1816); "Rotten and degenerated people” (Arndt, 1814); "bacteria” (Paul de Lagarde, 1887); "a horrible people” (Theodor Fontane, 1898); "mistake of world history" (Rudolf Steiner, 1888); “Decomposing power” (program of the German Social Party, Leipzig 1905); “[...] the judge had the Jew taken to the gallows and hanged as a thief." (The Jew among Thorns, Grimm's Fairy Tales); “Maiden murdered by Jews," (Legends book of Grimm's). The resurgence of antisemitism after the Holocaust reveals how deep its roots are in society. ${ }^{59}$ It has been fostered for such a long time in all European countries that one must consider it as inherent to European culture and a part of European values. It has turned into a tradition of thinking and feeling, stored in the collective memory of European society. As a tradition, antisemitism continues to exist in public discourse and in the mainstream mass media: On the streets ("Child murderer”), TV (e.g., Talk shows), in left-wing newspapers, in right-wing journals, in religious journals, in radio programs, in schools, in cabaret presentations, popular music, caricatures, in universities, and "conferences."

\section{No End to Antisemitism...}

Jew-hatred, then, did not vanish after the Holocaust, nor was it pushed to the edges of society. What happened was that antisemitism, in a temporarily subdued form, continued to exist in the middle of Western society, a fact that may be hard to accept and difficult to cope with, especially for Germans. An end to Judeophobia is apparently not in view, but steps can be taken to prevent its increase and especially, to control its peculiar kind of social normalization that occurs at the present-day internet communication.

A first step in the fight against present-day Jew-hatred is to get rid of wrong conceptualizations of the phenomenon. It must be recognized what antisemitism is not: it is not a social prejudice system; it is not necessarily connected to rac-

59 Cf. also R. Wistrich, Antisemitism: The Longest Hatred (London: Thames Mandarin, 1992); D. Nirenberg, Anti-Judaism: The Western Tradition (New York: W. W. Norton, 2013). 
ism; it does not mean a general bias against a certain minority; it has nothing to do with anti-modernism.

Antisemitism should be understood by what it is: a unique cultural category that has been communicated for many centuries and is deeply embedded in the societal mindset and behavior and has become an integral element of Western culture. As such, Jew-hatred has to be dealt with in new ways.

\section{Antisemitism 2.0-Something New?}

Antisemitism 2.0 reflects age-old Judeophobic arguments and emotional resentments. Jew-hatred on the internet is based on these stereotypes and feelings, and antisemitism 2.0 is the mirror image of everyday antisemitism in the real world.

Present-day antisemitism 2.0 shows the persistence of classical stereotypes and argumentation patterns. Verbal antisemitism has a characteristic of uniformity, since in the content of the argumentation there hardly is a difference between the social right, left, or middle or Muslim. A recurring conceptualization is that "Jews are the evil in the world," which is now re-activated as "Israel is the evil in the world."

However, the Web 2.0 has given new speed and intensification to antisemitism, adding to the globalization and intensification of Jew-hatred. The communication between the users of the web is more radical, since it is anonymous and less restricted. Multipliers and promotors in social media enhance the "normalization" of communications, as well as their social acceptability. It is difficult to fight antisemitism on the web if one does not take into account its omnipresence and habituality on everyday webpages. Antisemitic utterances are found on all mainstream levels of the web, also on sites not necessarily connected to racism and xenophobia. Antisemitism 2.0 is an expression of the age-old Jew-hatred with certain adaptions, but in its essence, it is the same hatred. Multiple expressions of the classical antisemitism do remain, to which new elements are added, in the present Israel-related focus.

\section{Conclusions}

The internet has changed the way in which we relate to the world, how we communicate, and how we process information. The Web 2.0 has brought new speed and a significant intensification to the articulation of antisemitism, and the international interconnectivity adds a new intensity to the globalization of Jew-hatred. The characteristics of the internet communication facilitate the immerging 
into an antisemitic world view. Users of the web communicate more radically and are less restrained, not only because much of the communication takes place anonymously but also due to the echo-chambers effect in antisemitic discourse that enhances the feeling of belonging to a community where this kind of discourse is justified. Especially young people tend to feel at home in the virtual world of the Web 2.0, where they easily find emotional bonding and cognitive support for their feelings. All these multipliers and promotors in social media enhance the normalization and social acceptability of Jew-hatred and anti-Israelism. To counteract these developments, especially this pattern of normalization of Jew-hatred with its diverse expressions, a determined social and political effort is necessary. How can the various forms of antisemitism 2.0 be confronted? One step in that direction is to fully recognize the dangers that the new communication technologies open for the spread of antisemitism in mainstream society. Another step is to acknowledge that antisemitism is a cultural category with a strong emotional dimension and not a mere prejudice.

In order to minimize antisemitism 2.0, it is not enough to delete or to prohibit or to give new laws. A new approach, including both virtual and real world, in combating antisemitism is needed.

Monika Schwarz-Friesel is a cognitive scientist and she holds the chair of cognitive media linguistics at the Technical University of Berlin. In her research, she specializes on the mental patterns and verbal manifestations of contemporary antisemitism. Her publications include several books on antisemitism, e.g. Inside the Antisemitic Mind, with Jehuda Reinharz, 2017. Her current research deals with Jew hatred on the Web 2.0 and with the emotional dimension of Antisemitism.

\section{Bibliography}

Belihart, Katharina. "Wie antisemitisch sind Kollegah und Farid Bang?" Frankfurter Allgemeine Zeitung, April 3, 2018. https://www.faz.net/aktuell/feuilleton/pop/anti semitismus-vorwuerfe-gegen-echo-nominierte-15524595.html.

Bundesverband Musikindustrie. "Presseinformation: Zur Diskussion um das Album "JBG3" von Kollegah \& Farid Bang sowie zum Beschluss des ECHO-Beirats.” Issued April 6, 2018. Accessed June 10, 2018. http://www.echopop.de/fileadmin/echopop/upload/ news/2018/Presseinformation_zur_Diskussion_um_das_Album_BG3_und_zum_Beir atsbeschluss.pdf

Cohen-Almagor, Raphael. Confronting the Internet's Dark Side: Moral and Social Responsibility on the Free Highway. New York: Cambridge University Press, 2015. 
Demnitz, Jana. "Solidaritätskundgebung 'Berlin trägt Kippa': 'Heute hat sich etwas verändert'.” Der Tagesspiegel, April 25, 2018. https://www.tagesspiegel.de/berlin/solid aritaetskundgebung-berlin-traegt-kippa-heute-hat-sich-etwas-veraendert/21215618.html.

Eddy, Melissa, and Andrew Curry. "Fury in Germany as Rap Duo With Anti-Jewish Lyrics Gets Award.” The New York Times, April 18, 2018. https://www.nytimes.com/2018/04/18/ arts/music/anti-semitism-german-rap.html.

Eddy, Melissa, and Alex Marshall. “Unwelcome Sound on Germany’s Stages: Musicians Who Boycott Israel.” The New York Times, July 1, 2018. https://www.nytimes.com/2018/07/ 01/arts/music/bds-germany-young-fathers.html.

Foxman, Abraham, and Christopher Wolf, eds. Viral Hate: Containing Its Spread on the Internet. New York: Palgrave Macmillan, 2013.

Iganski, Paul, and Abe Sweiry. "Antisemitism on Social Media." Lecture for the Panel Internet and Antisemitism, Conference “An End to Antisemitism!", University of Vienna, Vienna, February 21, 2018.

Institute for the Study of Contemporary Antisemitism. Best Practices to Combat Antisemitism on Social Media: Research Report to the U.S. Department of State Office of Religion and Global Affairs. Bloomington: Indiana University, 2017.

Lehrke, Gerhard. "Eklat an Humboldt-Uni Knesset-Abgeordnete bei Podiumsgespräch niedergebrüllt.” Berliner Zeitung, June 22, 2017. https://www.berliner-zeitung.de/berlin/ eklat-an-humboldt-uni-knesset-abgeordnete-bei-podiumsgespraech-niedergebruellt27845640.

Mearsheimer, John, and Stephen M. Walt. The Israel Lobby and U.S. Foreign Policy. New York: Farrar, Straus and Giroux, 2007.

N.N. “Der ganze Liedtext ist voll von Codes.” welt.de, January 31, 2018. https://www.welt.de/ vermischtes/article173042642/Lisa-Fitz-bedient-mit-YouTube-Song-antisemitische-Versch woerungstheorien.html.

N.N. “Europe's Largest Teachers' Union Endorses Israel Boycott Call.” Middle East Monitor, May 3, 2014. https://www.middleeastmonitor.com/20140503-europes-largest-teachersunion-endorses-israel-boycott-call/.

N.N. "Sigmar Gabriel, die Apartheid und ein Lob von der Hamas." Audiatur Online, January 4, 2018. https://www.audiatur-online.ch/2018/01/04/sigmar-gabriel-die-apartheid-und-einlob-von-der-hamas/.

N.N. "SPD-Chef kritisiert israelische Siedlungspolitik." Süddeutsche Zeitung, March 19, 2012. https://www.sueddeutsche.de/politik/kritik-an-siedlungspolitik-spd-chef-nennt-israelapartheid-regime-1.1309595.

N.N. “Stimme erheben: Nie wieder Judenhass!” Bild Zeitung, July 25, 2014. https://www.bild. de/politik/inland/antisemitismus/nie-wieder-judenhass-36968206.bild.html.

Nirenberg, David. Anti-Judaism: The Western Tradition. New York: W. W. Norton, 2013.

Oboler, Andre. "Solving Antisemitic Hate Speech in Social Media through a Global Approach to Local Action." Lecture for the Panel Internet and Antisemitism, Conference "An End to Antisemitism!", University of Vienna, Vienna, February 22, 2018.

Rathje, Jan. "Antisemitism in Post-Holocaust Conspiracy Ideologies." Lecture for the Panel Internet and Antisemitism, Conference "An End to Antisemitism!", University of Vienna, Vienna, February 21, 2018.

Reuters Institute. Digital News Report 2017. Accessed June 10, 2018. http://www.digital newsreport.org/survey/2017/overview-key-findings-2017. 
Rosenberg, Yair. "Stanford Student Senator: Saying 'Jews Control the Media, Economy, Government' is 'Not Anti-Semitism."' Tablet Magazine, April 7, 2016. https://www.tablet mag.com/scroll/199362/stanford-student-senator-saying-jews-control-the-media-econo my-government-is-not-anti-semitism.

Schwarz-Friesel, Monika. "Antisemitism 2.0. Hostility towards Jews as a Cultural Constant and Collective Emotional Value in the Digital Age." Longitudinal corpus study, Technische Universität Berlin, Berlin, 2018. https://www.linguistik.tu-berlin.de/menue/anti semitismus_2_0/.

Schwarz-Friesel, Monika. "Antisemitism 2.0 and the Cyberculture of Hate: Hostility towards Jews as a Cultural Constant and Collective Emotional Value in the Digital Age (Short Version)." Technische Universität Berlin, Berlin, 2018. https://www.linguistik.tu-berlin. de/fileadmin/fg72/Antisemitism_2.0_short_version_final.pdf.

Schwarz-Friesel, Monika. "Educated Anti-Semitism in the Middle of German Society. Empirical Findings." In Being Jewish in 21st-Century Germany, edited by Haim Fireberg and Olaf Glöckner, 165-87. Oldenbourg: de Gruyter, 2015.

Schwarz-Friesel, Monika. Judenhass im Internet: Antisemitismus als kulturelle Konstante und kollektives Gefühl. Leipzig: Hentrich und Hentrich, 2019.

Schwarz-Friesel, Monika, and Jehuda Reinharz. Inside the Antisemitic Mind: The Language of Jew-Hatred in Contemporary Germany. Boston: University Press of New England, 2017.

Schwarz-Friesel, Monika, and Jehuda Reinharz. "The Israelization of Antisemitism." The Jerusalem Post, February 16, 2017. https://www.jpost.com/Opinion/The-Israelization-ofantisemitism-481835.

Schwarz-Friesel, Monika. “Juden sind zum Töten da’ (studivz.net, 2008). Hass via InternetZugänglichkeit und Verbreitung von Antisemitismen im World Wide Web." In Sprache und Kommunikation im technischen Zeitalter. Wieviel Internet (v)erträgt unsere Gesellschaft? edited by Konstanze Marx and Monika Schwarz-Friesel, 213-36. Berlin: de Gruyter Saur, 2013.

Simon, Marcel. Versus Israel: A Study of the Relations between Christians and Jews in the Roman Empire AD 135-425. Oxford: University Press, 1996.

Trachtenberg, Joshua. The Devil and the Jews: The Medieval Conception of the Jew and its Relation to Modern Antisemitism. New Haven: Yale University Press, 1943.

Unabhängiger Expertenkreis Antisemitismus. "Bericht des Unabhängigen Expertenkreises Antisemitismus.” Issued April 7, 2017. http://dip21.bundestag.de/dip21/btd/18/119/ 1811970.pdf.

University College London Union. "Union Policy UP1514: Motion: In support of BDS at UCLU.” Issued March 7, 2018. https://studentsunionucl.org/sites/uclu.org/files/policies/up1514. pdf.

Weitzman, Mark. "The Internet is Our Sword: Aspects of Online Antisemitism." In Remembering for the Future: The Holocaust in an Age of Genocide, edited by John K. Roth and Elisabeth Maxwell-Meynard, 925-91. New York: Palgrave, 2001.

Wildman, Sarah. "German Court Rules that Firebombing a Synagogue is not anti-Semitic." Vox, January 13, 2017. https://www.vox.com/world/2017/1/13/14268994/synagogue-wup pertal-anti-semitism-anti-zionism-anti-israel.

Wistrich, Robert. Antisemitism: The Longest Hatred. London: Thames Mandarin, 1992. 
Zappavigna, Michele. Discourse of Twitter and Social Media: How We Use Language to Create Affiliation on the Web. London: Bloomsbury, 2012.

Zick, Andreas, Andreas Hövermann, Silke Jensen, and Julia Bernstein. Jüdische Perspektiven auf Antisemitismus in Deutschland. Ein Studienbericht für den Expertenrat Antisemitismus. Bielefeld: Universität Bielefeld, 2017. Accessed September 6, 2017. https://uni-bielefeld.de/ikg/daten/JuPe_Bericht_April2017.pdf. 
